\title{
Relationship between Myeloid-Related Protein 8/14 and Survival of Chinese Peritoneal Dialysis Patients
}

\author{
Peter Yam-Kau Poon Cheuk-Chun Szeto Bonnie Ching-Ha Kwan \\ Kai-Ming Chow Chi-Bon Leung Philip Kam-Tao Li \\ Departments of Medicine and Therapeutics, Prince of Wales Hospital, The Chinese University of Hong Kong, \\ Hong Kong, SAR, China
}

\section{Key Words}

Inflammation - Renal failure $\cdot$ Cardiovascular disease $\cdot$

Myeloid-related protein $8 / 14$

\begin{abstract}
Background: Myeloid-related protein 8/14 (MRP8/14) is released by cells of myeloid lineage upon inflammatory challenges. Experimental data suggested that MRP8/14 is important in the initiation and progression of inflammation and cardiovascular diseases. We examined the relation between serum MRP8/14 level and cardiovascular disease in Chinese peritoneal dialysis (PD) patients. Methods: We studied 102 new PD patients (58 males, mean age $57.3 \pm 11.9$ years). Baseline serum MRP8/14 was determined and grouped to quartiles for analysis. All patients were then followed for an average of $23.9 \pm 6.9$ months. Results: There was a trend of lower 3-year cardiovascular event-free survival for patient quartiles with high serum MRP8/14 levels (log-rank test, $p=$ $0.064)$. The 3 -year actuarial survival was significantly lower for quartile groups with higher MRP8/14 levels (96.0, 94.7, 72.9 , and $62.5 \%$ for quartiles $1-4$, respectively, $p=0.003$ ). Cox regression analysis showed that serum MRP8/14 level and $\mathrm{Kt} / \mathrm{V}$ were independent predictors of actuarial survival; in this model, every $1 \mu \mathrm{g} / \mathrm{ml}$ increase in serum MRP8/14 level
\end{abstract}

confers a $25.1 \%$ increase in risk of death (95\% confidence interval, $1.3-54.4 \%, p=0.037$ ). There was no significant difference in technique survival between the MRP8/14 quartile groups. Conclusion: A high baseline serum MRP8/14 level was associated with a lower actuarial survival in Chinese PD patients. The pathogenic role of MRP8/14 in the cardiovascular disease of PD patients needs further investigation.

Copyright $\odot 2012$ S. Karger AG, Basel

\section{Introduction}

Peritoneal dialysis (PD) is the first-line renal replacement therapy in Hong Kong [1, 2]. Most PD patients can enjoy an impressive survival rate and an excellent quality of life during the treatment [2]. However, PD is known to cause inflammation and oxidative stress, which may aggravate atherosclerotic lesions [3-7]. In fact, cardiovascular disease is the major cause of morbidity and mortality in PD patients $[8,9]$. Glucose, glucose degradation products and advanced glycation end products in the PD solutions are probably the major causative factors of inflammation in PD process [10-13]. However, the exact pathogenic mechanism of accelerated atherosclerosis and systemic inflammation in PD remains unclear.

\section{KARGER}

Fax +41613061234 E-Mail karger@karger.ch www.karger.com
(C) 2012 S. Karger AG, Basel

$1420-4096 / 12 / 0356-0489 \$ 38.00 / 0$

Accessible online at:

www.karger.com/kbr
Dr. C.C. Szeto

Department of Medicine and Therapeutics, Prince of Wales Hospital

The Chinese University of Hong Kong

Shatin, N.T., Hong Kong, SAR (China)

Tel. +852 2632 3126, E-Mail ccszeto@ cuhk.edu.hk 
Myeloid-related protein $8 / 14(\mathrm{MRP} / 14)$ is a $24-\mathrm{kDa}$ heterodimer of 2 calcium-binding proteins MRP8 (also called S100A8) and MRP14 (also called S100A9) [14, 15]. Cells of myeloid origin (neutrophils and monocytes), epithelial cells and platelets are the sources of MRP8 and MRP14 [16-18]. Upon cell activation such as contacted with inflamed endothelium, MRP8 and MRP14 associate to form the MRP8/14 complex, which is then transported to the cell membrane and secreted to the extracellular environment [19-21]. There is a wealth of experimental data suggesting that MRP8/14 is important in the initiation and progression of the inflammatory process [2227]. Some clinical studies also demonstrated a link between MRP8/14 expression and cardiovascular diseases [28-31]. However, the contribution of MRP8/14 to the systemic inflammation and cardiovascular disease in PD patients has not been explored. In the present study, we examined the relation between serum MRP8/14 levels and the risk of cardiovascular events and mortality of Chinese PD patients.

\section{Methods}

\section{Study Population}

From April 2007 to September 2008, we studied 104 consecutive new PD patients. All patients were started with 2-liter PD exchanges three times a day. Those who were unlikely to survive for 6 months, who planned to have elective living donor transplant or who would be transferred to other renal centers within 6 months were excluded. The presence of diabetes, hypertension, and a history of cardiovascular disease were recorded. Hypertension was defined according to the Joint National Committee VII criteria [32]. The definition of cardiovascular disease has been described previously [33]. Serum MRP8/14 protein and C-reactive protein (CRP) levels were measured at the initiation of dialysis when patients were free of peritonitis and any other acute infection or inflammation for at least one month. CRP was quantified by our in-house high-sensitivity assay. This study was approved by the Clinical Research Ethical Committee of the Chinese University of Hong Kong. Informed consent was obtained from all the patients.

\section{MRP8/14 Assay}

Baseline serum samples were obtained from clotted bloods of the patients and stored at $-85^{\circ} \mathrm{C}$ until the assays started. MRP8/14 enzyme-linked immunoabsorbant assay kits were purchased from Bühlmann Laboratories AG (Schönenbuch, Switzerland). The assay was done according to the instruction supplied with the kit. The limit of detection of the assay was lower than $0.4 \mu \mathrm{g} / \mathrm{ml}$. The intra-assay and inter-assay coefficients of variation were 4.3 and $5.8 \%$, respectively. Two patients were subsequently excluded from the study because they were unexplained outliers of serum MRP8/14 levels.

\section{Clinical Follow-Up}

All patients were followed until March 2010. The clinical management and dialysis regimen were decided by individual nephrologists and not affected by the study. Primary end point was hospital admission for pulmonary edema, unstable angina, or coronary intervention. Secondary end points included actuarial survival, technique survival, and peritonitis-free survival. Censoring events for actuarial survival included transfer to long-term hemodialysis, kidney transplant, recovery of renal function, loss to follow-up, and transfer to other dialysis centers. Technique survival was defined as being alive and remaining on $\mathrm{PD}$.

\section{Statistical Analysis}

Statistical analysis was performed by SPSS for Windows software version 15.0 (SPSS Inc., Chicago, Ill., USA). Data were expressed as mean \pm standard deviation. Comparisons between groups were performed by the $\chi^{2}$ test, Student's $t$ test or one-way analysis of variance as appropriate. Regression analysis was used to investigate the correlation between two parameters. Serum MRP8/14 levels were grouped into quartiles 1-4 (with increasing MRP8/14 levels) for analysis. Kaplan-Meier analysis and the log rank test were used to explore the effect of MRP8/14 quartiles on the clinical end points. In addition to MRP8/14 quartiles, we also added baseline residual glomerular filtration rate (GFR), total $\mathrm{Kt} / \mathrm{V}$, serum albumin, subjective global assessment, Charlson's comorbidity score, age, and diabetic status into the Cox proportional hazard model to look for independent predictors of clinical outcome. Backward stepwise analysis was applied to remove insignificant variables. A p value below 0.05 was considered statistically significant. All probabilities were two tailed.

\section{Results}

We analyzed the results of 102 patients. The demographic and baseline clinical information of the patients in different quartiles are summarized and compared in table 1. Peritoneal transport, dialysis adequacy and nutritional status are compared in table 2. In short, all the baseline clinical and laboratory parameters were highly comparable among the 4 quartile groups except for the dialysate-to-plasma creatinine ratio at $4 \mathrm{~h}$ and weekly total Kt/V, where a slight difference was shown. There was no significant difference in the use of antihypertensive drugs or blockers of the renin-angiotensin system between the groups (details not shown). The average serum CRP level was $3.43 \pm 2.68 \mathrm{mg} / \mathrm{l}$. Serum MRP8/14 levels did not correlate with CRP levels $(\mathrm{p}=0.9)$; there was no significant difference in serum CRP levels between MRP8/14 quartile groups (details not shown). However, there was a modest but statistically significant inverse correlation between serum MRP8/14 level and residual GFR $(\mathrm{r}=-0.298, \mathrm{p}=0.004)$. 
Table 1. Baseline clinical and demographic data

\begin{tabular}{|c|c|c|c|c|}
\hline & \multicolumn{4}{|c|}{ MRP8/14 quartile } \\
\hline & 1 & 2 & 3 & 4 \\
\hline Patients & 25 & 26 & 25 & 26 \\
\hline $\mathrm{MRP} 8 / 14, \mu \mathrm{g} / \mathrm{ml}^{*}$ & $1.28 \pm 0.34$ & $2.46 \pm 0.35$ & $3.70 \pm 0.51$ & $7.53 \pm 2.91$ \\
\hline Males/females & $16 / 9$ & $15 / 11$ & $13 / 12$ & $14 / 12$ \\
\hline Age, years & $53.3 \pm 10.6$ & $57.5 \pm 10.8$ & $60.7 \pm 11.8$ & $57.8 \pm 13.7$ \\
\hline Body height, $\mathrm{cm}$ & $164.4 \pm 9.0$ & $161.3 \pm 6.2$ & $158.2 \pm 9.0$ & $159.8 \pm 8.3$ \\
\hline Body weight, kg & $64.1 \pm 15.8$ & $66.2 \pm 12.1$ & $58.8 \pm 11.6$ & $65.6 \pm 14.3$ \\
\hline Body mass index & $23.6 \pm 5.2$ & $25.4 \pm 4.5$ & $23.4 \pm 3.3$ & $25.5 \pm 4.0$ \\
\hline \multicolumn{5}{|l|}{ Renal diagnosis } \\
\hline Glomerulonephritis & $11(44.0)$ & $7(26.9)$ & $5(20.0)$ & $9(34.7)$ \\
\hline Diabetic nephropathy & $5(20.0)$ & $12(46.2)$ & $9(36.0)$ & $11(42.3)$ \\
\hline Polycystic kidney & $5(20.0)$ & $1(3.9)$ & $1(4.0)$ & $0(0.0)$ \\
\hline Hypertensive nephrosclerosis & $1(4.0)$ & $1(3.9)$ & $3(12.0)$ & $2(7.6)$ \\
\hline Obstructive uropathy & $0(0.0)$ & $3(11.5)$ & $1(4.0)$ & $0(0.0)$ \\
\hline Others/unknown & $3(12.0)$ & $2(7.6)$ & $6(24.0)$ & $4(15.4)$ \\
\hline \multicolumn{5}{|l|}{ Comorbid conditions } \\
\hline Coronary heart disease & $3(12.0)$ & $6(23.1)$ & $2(8.0)$ & $3(11.5)$ \\
\hline Cerebrovascular disease & $5(20.0)$ & $3(11.5)$ & $2(8.0)$ & $7(26.9)$ \\
\hline Peripheral vascular disease & $1(4.0)$ & $0(0.0)$ & $0(0.0)$ & $1(3.8)$ \\
\hline Charlson's comorbidity index & $4.4 \pm 2.1$ & $5.3 \pm 2.4$ & $5.2 \pm 1.9$ & $5.5 \pm 2.8$ \\
\hline
\end{tabular}

${ }^{*} \mathrm{p}<0.001$ between the groups. Figures in parentheses indicate percentages.

Table 2. Baseline peritoneal transport, dialysis adequacy and nutritional status

\begin{tabular}{lllll}
\hline & \multicolumn{2}{l}{ MRP8/14 quartile } & \\
\cline { 2 - 4 } & 1 & 2 & 3 & 4 \\
\hline Patients & 25 & 26 & 25 & 26 \\
Peritoneal transport & & & \\
$\quad$ D/P creatinine at $4 \mathrm{~h}^{*}$ & & & \\
$\quad$ MTAC creatinine, $\mathrm{ml} / \mathrm{min} / 1.73 \mathrm{~m}^{2}$ & $7.85 \pm 4.06$ & $7.09 \pm 3.72$ & $5.91 \pm 4.26$ & $7.25 \pm 3.75$ \\
Dialysis adequacy and nutritional status & & & & \\
$\quad$ Weekly total Kt/V & $2.29 \pm 0.72$ & $2.16 \pm 0.52$ & $2.46 \pm 0.78$ & $1.91 \pm 0.49$ \\
$\quad$ Residual GFR, $\mathrm{ml} / \mathrm{min} / 1.73 \mathrm{~m}^{2}$ & $5.36 \pm 3.82$ & $4.46 \pm 2.85$ & $4.03 \pm 3.79$ & $2.66 \pm 2.41$ \\
$\quad$ Serum albumin, g/l & $35.1 \pm 3.8$ & $34.0 \pm 3.6$ & $35.7 \pm 3.8$ & $33.7 \pm 5.4$ \\
$\quad$ NPNA, g/kg/day & $1.11 \pm 0.28$ & $1.14 \pm 0.32$ & $1.20 \pm 0.32$ & $1.13 \pm 0.25$ \\
$\quad$ FEBM, \% & $37.9 \pm 9.2$ & $37.8 \pm 7.5$ & $43.9 \pm 12.7$ & $43.1 \pm 10.9$ \\
\hline
\end{tabular}

$\mathrm{D} / \mathrm{P}=$ Dialysate-to-plasma ratio; $\mathrm{MTAC}=$ mass transfer area coefficient; NPNA $=$ normalized protein nitrogen appearance; FEBM = fat-free edema-free body mass.

${ }^{*} \mathrm{p}<0.05$ between the groups. 
Fig. 1. Kaplan-Meier plot of event-free survival for PD patients with different MRP8/14 quartiles.

Fig. 2. Kaplan-Meier plot of actuarial survival for PD patients with different MRP8/14 quartiles.
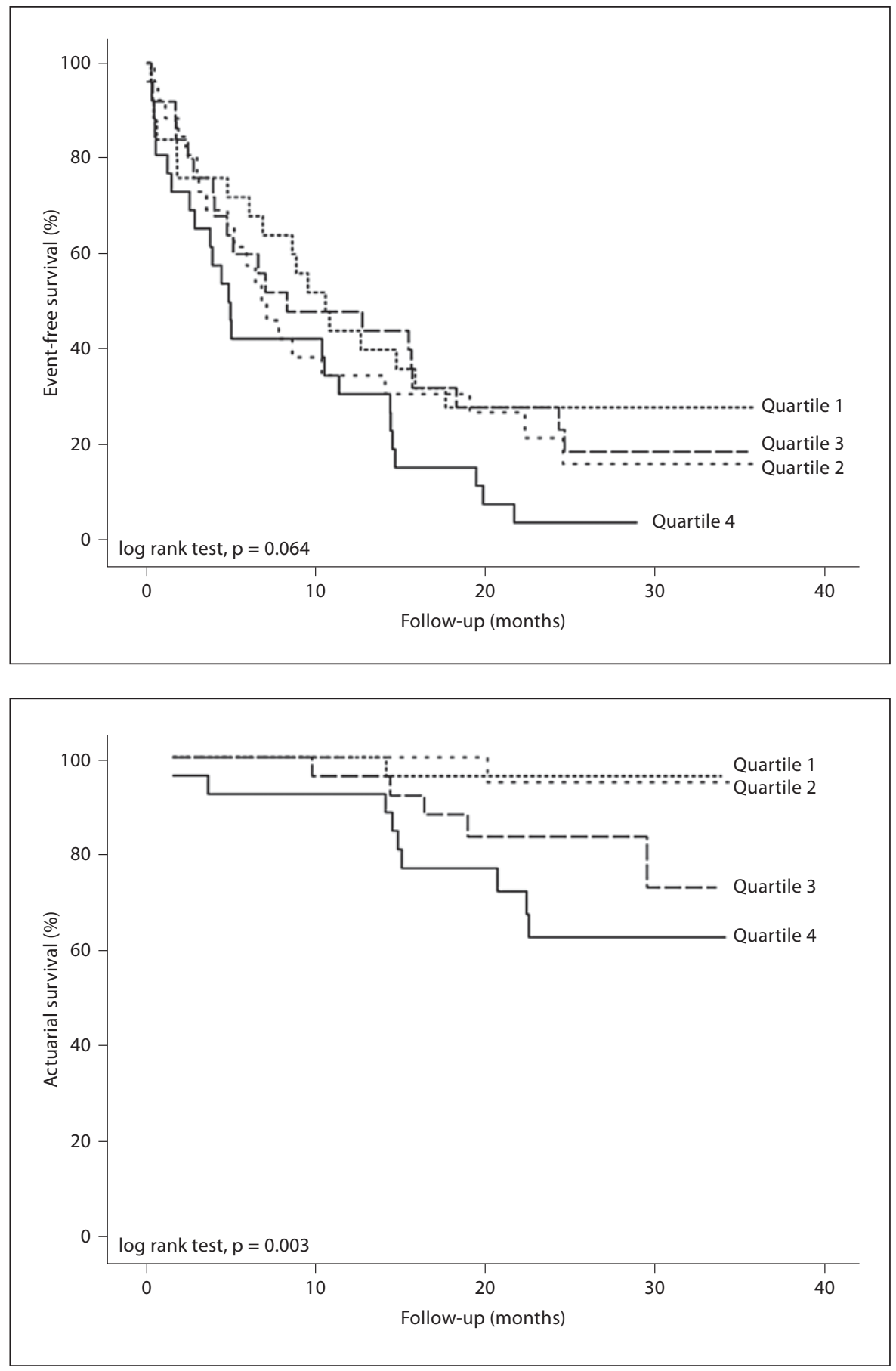

\section{Primary End Point}

The average follow-up was $23.9 \pm 6.9$ months. During the study period, 84 patients $(82.4 \%)$ developed the primary end point. There was a trend of lower 3-year eventfree survival for groups with higher serum MRP8/14 levels $(28.0,16.2,18.7$, and $3.8 \%$ for quartiles $1-4$, respec- tively; log rank test, $\mathrm{p}=0.064$; fig. 1). However, the difference did not reach statistical significance.

\section{Secondary End Points}

During the follow-up period, 16 (15.7\%) patients died. The causes of death were acute coronary syndrome (6 
Fig. 3. Kaplan-Meier plot of technique survival for $\mathrm{PD}$ patients with different MRP8/14 quartiles.

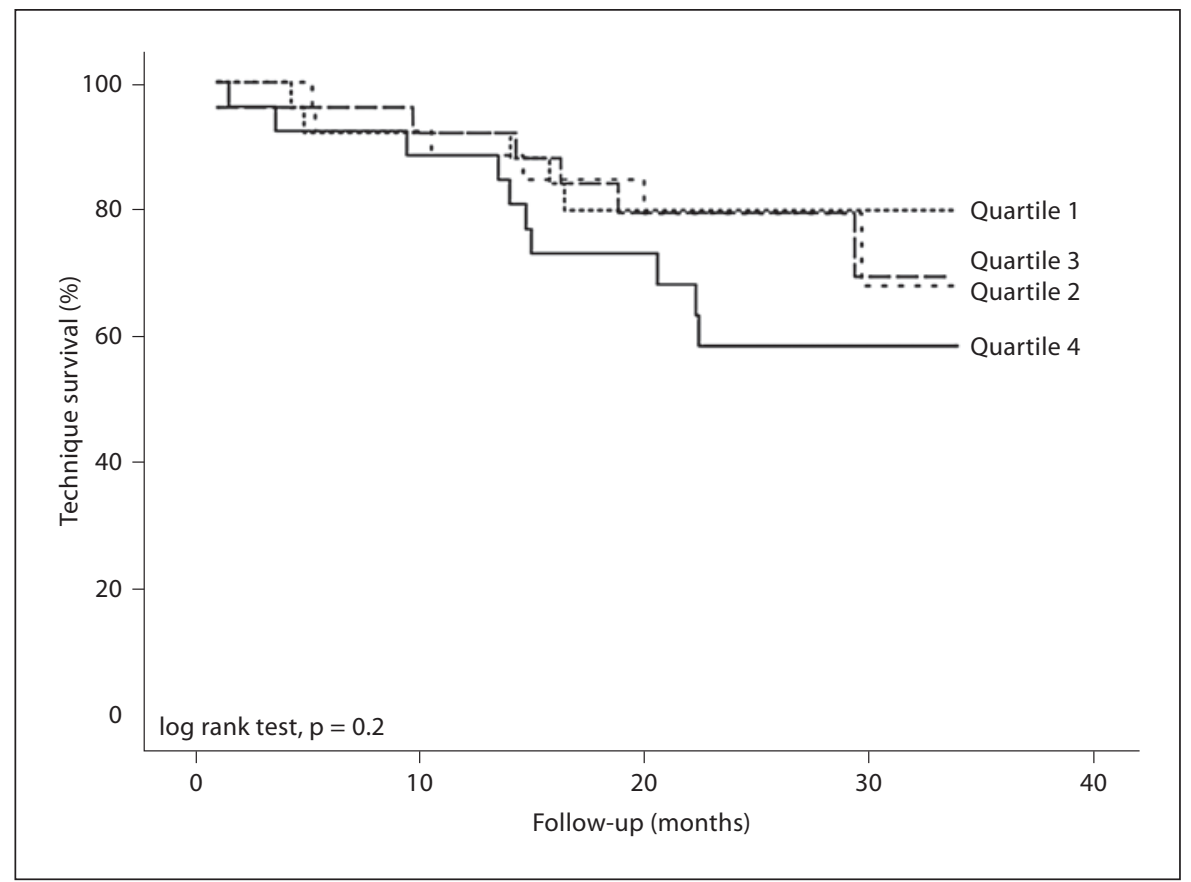

Table 3. Multivariate analysis by Cox model for actuarial survival

\begin{tabular}{llll}
\hline & AHR & $95 \%$ CI & $\begin{array}{l}\text { p } \\
\text { value }\end{array}$ \\
\hline MRP8/14 level & & & 0.037 \\
Kt/V & 1.251 & $1.013-1.544$ & $0.015-0.818$ \\
Presence of preexisting diabetes & 7.567 & $0.941-60.848$ & 0.057 \\
\hline
\end{tabular}

$\mathrm{AHR}=$ Adjusted hazard ratio $\mathrm{CI}=$ confidence interval.

cases), sudden cardiac death (5 cases), malignancy ( 2 cases), non-peritonitis infections ( 1 case), termination of dialysis ( 1 case) and suicide (1 case). The 3 -year actuarial survival was significantly lower for quartile groups with higher MRP8/14 levels (96.0, 94.7, 72.9, and 62.5\% for quartiles $1-4$, respectively; $\mathrm{p}=0.003$; fig. 2). Multivariate Cox regression analysis also showed that serum MRP8/14 level and $\mathrm{Kt} / \mathrm{V}$ were independent predictors of actuarial survival (table 3). In this model, every $1 \mu \mathrm{g} / \mathrm{ml}$ increase in serum MRP8/14 level confers a $25.1 \%$ increase in risk of death (95\% confidence interval, $1.3-54.4 \%, \mathrm{p}=0.037$ ).

During the study period, another 8 patients had kidney transplantation, 3 changed to hemodialysis and 1 was transferred to another center. There was no significant difference in the 3-year technique survival between the MRP8/14 level groups $(79.8 \%, 68.0,69.4$, and 58.5\% for quartiles $1-4$, respectively; $\mathrm{p}=0.2$; fig. 3 ). There was also no difference in the 3 -year peritonitis-free survival between the MRP8/14 level groups $(67.6,54.7,71.4$, and $43.7 \%$ for quartiles $1-4$, respectively; $\mathrm{p}=0.26$ ).

\section{Discussion}

To the best of our knowledge, this study is the first to investigate the effect of baseline serum MRP8/14 levels on the clinical outcome of PD patients. In essence, we found that patients having higher baseline serum MRP8/14 had significantly higher all-cause mortality and a marginally higher risk of cardiovascular events.

The exact mechanism that a high serum MRP8/14 level confers an increase in mortality risk is not clear. Most previous clinical reports pointed out that MRP8/14 is a sensitive marker of acute inflammation in other clinical conditions, such as Kawasaki disease, acute myocardial infarction, and kidney transplant rejection. In addition, Frosch et al. [21] demonstrated that monocytes secretedMRP8/14aftercontact with inflamed endothelium. In return, MRP8/14 stimulates endothelial cells to ex- 
press various inflammatory factors [26], and is essential for the migration of neutrophils to the site of inflammation [24].

Our result agrees with previous reports in non-renal failure patients. A number of previous studies showed that higher MRP8/14 levels correlated with a higher incidence of cardiovascular events $[28,29,31]$. Taken together, available evidence suggests that MRP8/14 is important in the initiation and progression of inflammation and atherosclerosis. It should be noted that a high baseline MRP8/14 level is associated with excess mortality risk throughout the 3 years of study period rather than being limited to the early months after dialysis (see fig. 1), suggesting that MRP8/14 reflects the degree of background systemic inflammatory state rather than being a direct precipitating factor of immediate infection episode or cardiovascular event.

On the other hand, the relationship between MRP8/14 and peritoneal inflammation has not been explored. As mentioned previously, PD solutions are inflammatory stimuli to the peritoneal cells $[34,35]$. In vitro studies indicated that activated endothelial cells could cause cellular release of MRP8/14 [19-21]. In addition, lowgrade endotoxemia is common in $\mathrm{PD}$ patients and may be related to cardiovascular diseases $[36,37]$. In vitro, lipopolysaccharide could induce MRP8/14 production by monocytes $[38,39]$. The relation between MRP8/14 and inflammation is therefore particularly complex in PD patients.

Although MRP8/14 is related to inflammation, our result does not show any correlation between serum MRP8/14 and CRP levels. This observation is consistent with the finding of Burkhardt et al. [30] who showed that CRP levels were not significantly different between diabetic nephropathy patients with MRP8/14 levels below and above the median value. Morrow et al. [29] found that serum CRP levels of patients with acute coronary syndrome were only weakly correlated with MRP8/14 levels. Furthermore, serum MRP8/14 has been reported to be a more sensitive marker than CRP. For example, Ikemoto et al. [40] showed that serum MRP8/14 appeared earlier than CRP in a patient with partial small intestine transplant rejection. Patients with acute ST-segment elevation myocardial infarction had significantly higher serum levels of MRP8/14, but not CRP, than patients with stable coronary artery disease [18]. In our cohort, the CRP levels did not differ between the 4 MRP8/14 quartile groups. Our study indirectly suggests that baseline serum MRP8/14 may be more sensitive than serum CRP as a prognostic marker of PD patients.
There are a number of inadequacies of our present study. First, because of the limitation in the original design of the study, we had the baseline but not any followup MRP8/14 levels, which may shed light on the role of serum MRP8/14 level for serial monitoring. Similarly, we did not compare the serum MRP8/14 levels before and after PD was started; although PD is unlikely to remove substantial amount of MRP8/14 protein from the serum, it remains possible that the procedure of PD per se induces some low-grade inflammation or macrophage activation, resulting in an increase in serum MRP8/14 levels. Secondly, we did not explore the relationship between serum MRP8/14 level and other inflammatory markers (for example, serum interleukin-6 or circulating endothelial progenitor cell), and the relation between MRP8/14 and systemic inflammation has not been clearly worked out.

Last but not least, the sample size of our study was limited. It could be estimated that a significant difference in the rate of cardiovascular events could only be detected if the sample size is increased to over $200 \mathrm{pa}$ tients.

In conclusion, baseline serum MRP8/14 level was associated with all-cause mortality and probably cardiovascular events in Chinese PD patients. The mechanism through which MRP8/14 leads to excessive mortality and cardiovascular disease deserves further investigation.

\section{Acknowledgements}

This study was supported in part by the CUHK research accounts 6901031 and 7101215, and the Richard Yu Peritoneal Dialysis Research Fund.

\section{Disclosure Statement}

The authors declare no conflict of interest. 


\section{References}

1 Yu AWY, Chau KF, Ho YW, Li PKT: Development of the 'peritoneal dialysis first' model in Hong Kong. Perit Dial Int 2007;27(suppl 2):S53-S55.

-2 Li PKT, Szeto CC: Success of the peritoneal dialysis programme in Hong Kong. Nephrol Dial Transplant 2008;23:1475-1478.

-3 Ducloux D, Bresson-Vautrin C, Kribs M, Abdelfatah A, Chalopin JM: C-reactive protein and cardiovascular disease in peritoneal dialysis patients. Kidney Int 2002;62:14171422.

-4 Cangemi R, Angelico F, Loffredo L, Del Ben M, Pignatelli P, Martini A, Violi F: Oxidative stress-mediated arterial dysfunction in patients with metabolic syndrome: effect of ascorbic acid. Free Radic Biol Med 2007;43: 853-859.

5 Stephens JW, Bain SC, Humphries SE: Gene-environment interaction and oxidative stress in cardiovascular disease. Atherosclerosis 2008;200:229-238.

-6 Heistad DD, Wakisaka Y, Miller J, Chu Y, Pena-Silva R: Novel aspects of oxidative stress in cardiovascular diseases. Circ J 2009; 73:201-207.

-7 Choi HY, Lee JE, Han SH, Yoo TH, Kim BS, Park HC, Kang SW, Choi KH, Ha SK, Lee HY, Han DS: Association of inflammation and protein-energy wasting with endothelial dysfunction in peritoneal dialysis patients. Nephrol Dial Transplant 2010;25:12661271.

8 Li PKT, Chow KM: The Clinical and Epidemiological Aspects of Vascular Mortality in Chronic Peritoneal Dialysis Patients. Perit Dial Int 2005;25(suppl 3):S80-S83.

-9 Krediet RT, Balafa O: Cardiovascular risk in the peritoneal dialysis patient. Nat Rev Nephrol 2010;6:451-460.

$\checkmark 10$ Ha H, Yu MR, Lee HB: High glucose-induced PKC activation mediates TGF-beta 1 and fibronectin synthesis by peritoneal mesothelial cells. Kidney Int 2001;59:463-470.

11 Welten AG, Schalkwijk CG, ter Wee PM, Meijer S, van den Born J, Beelen RJ: Single exposure of mesothelial cells to glucose degradation products (GDPs) yields early advanced glycation end-products (AGEs) and a proinflammatory response. Perit Dial Int 2003;23:213-221.

-12 Inagi R, Miyata T, Yamamoto T, Suzuki D, Urakami K, Saito A, van Ypersele de Strihou C, Kurokawa K: Glucose degradation product methylglyoxal enhances the production of vascular endothelial growth factor in peritoneal cells: role in the functional and morphological alterations of peritoneal membranes in peritoneal dialysis. FEBS Lett 1999; 463:260-264.

13 Boulanger E, Wautier MP, Wautier JL, Boval B, Panis Y, Wernert N, Danze PM, Dequiedt P: AGEs bind to mesothelial cells via RAGE and stimulate VCAM-1 expression. Kidney Int 2002;61:148-156.
14 Bhardwaj RS, Zotz C, Zwadlo-Klarwasser G, Roth J, Goebeler M, Mahnke K, Falk M, Meinardus-Hager G, Sorg C: The calcium-binding proteins MRP8 and MRP14 form a membrane-associated heterodimer in a subset of monocytes/macrophages present in acute but absent in chronic inflammatory lesions. Eur J Immunol 1992;22:1891-1897.

15 Hunter MJ, Chazin WJ: High level expression and dimer characterization of the S100 EF-hand proteins, migration inhibitory factor-related proteins 8 and 14. J Biol Chem 1998;273:12427-12435.

16 Hessian PA, Edgeworth J, Hogg N: MRP-8 and MRP-14, two abundant $\mathrm{Ca}^{2+}$-binding proteins of neutrophils and monocytes. J Leukoc Biol 1993;53:197-204.

17 Henke MO, Renner A, Rubin BK, Gyves JI, Lorenz E, Koo JS: Up-regulation of S100A8 and S100A9 protein in bronchial epithelial cells by lipopolysaccharide. Exp Lung Res 2006;32:331-347.

18 Healy AM, Pickard MD, Pradhan AD, Wang Y, Chen Z, Croce K, Sakuma M, Shi C, Zago AC, Garasic J, Damokosh AI, Dowie TL, Poisson L, Lillie J, Libby P, Ridker PM, Simon DI: Platelet expression profiling and clinical validation of myeloid-related protein-14 as a novel determinant of cardiovascular events. Circulation 2006;113:2278-2284.

19 Teigelkamp S, Bhardwaj RS, Roth J, Meinardus-Hager G, Karas M, Sorg C: Calcium-dependent complex assembly of the myeloic differentiation proteins MRP-8 and MRP14. J Biol Chem 1991;266:13462-13467.

20 Rammes A, Roth J, Goebeler M, Klempt M, Hartmann M, Sorg C: Myeloid-related protein (MRP) 8 and MRP14, calcium-binding proteins of the $S 100$ family, are secreted by activated monocytes via a novel, tubulin-dependent pathway. J Biol Chem 1997;272: 9496-9502.

21 Frosch M, Strey A, Vogl T, Wulffraat NM, Kuis W, Sunderkötter C, Harms E, Sorg C, Roth J: Myeloid-related proteins 8 and 14 are specifically secreted during interaction of phagocytes and activated endothelium and are useful markers for monitoring disease activity in pauciarticular-onset juvenile rheumatoid arthritis. Arthritis Rheum 2000; 43:628-637.

22 Srikrishna G, Panneerselvam K, Westphal V, Abraham V, Varki A, Freeze HH: Two proteins modulating transendothelial migration of leukocytes recognize novel carboxylated glycans on endothelial cells. J Immunol 2001;166:4678-4688.

23 Robinson MJ, Tessier P, Poulsom R, Hogg N: The S100 family heterodimer, MRP-8/14, binds with high affinity to heparin and heparan sulfate glycosaminoglycans on endothelial cells. J Biol Chem 2002;277:36583665 .
24 Vandal K, Rouleau P, Boivin A, Ryckman C, Talbot M, Tessier PA: Blockade of S100A8 and S100A9 suppresses neutrophil migration in response to lipopolysaccharide. J Immunol 2003;171:2602-2609.

25 Manitz MP, Horst B, Seeliger S, Strey A, Skryabin BV, Gunzer M, Frings W, Schönlau F, Roth J, Sorg C, Nacken W: Loss of S100A9 (MRP14) results in reduced interleukin-8induced CD11b surface expression, a polarized microfilament system, and diminished responsiveness to chemoattractants in vitro. Mol Cell Biol 2003;23:1034-1043.

26 Viemann D, Strey A, Janning A, Jurk K, Klimmek K, Vogl T, Hirono K, Ichida F, Foell D, Kehrel B, Gerke V, Sorg C, Roth J: Myeloid-related proteins 8 and 14 induce a specific inflammatory response in human microvascular endothelial cells. Blood 2005; 105:2955-2962.

27 Croce K, Gao H, Wang Y, Mooroka T, Sakuma M, Shi C, Sukhova GK, Packard RR, Hogg N, Libby P, Simon DI: Myeloid-related protein-8/14 is critical for the biological response to vascular injury. Circulation 2009; 120:427-436.

28 Altwegg LA, Neidhart M, Hersberger M, Müller S, Eberli FR, Corti R, Roffi M, Sütsch G, Gay S, von Eckardstein A, Wischnewsky MB, Lüscher TF, Maier W: Myeloid-related protein $8 / 14$ complex is released by monocytes and granulocytes at the site of coronary occlusion: a novel, early, and sensitive marker of acute coronary syndromes. Eur Heart J 2007;28:941-948.

29 Morrow DA, Wang Y, Croce K, Sakuma M, Sabatine MS, Gao H, Pradhan AD, Healy AM, Buros J, McCabe CH, Libby P, Cannon CP, Braunwald E, Simon DI: Myeloid-related protein 8/14 and the risk of cardiovascular death or myocardial infarction after an acute coronary syndrome in the Pravastatin or Atorvastatin Evaluation and Infection Therapy: Thrombolysis in Myocardial Infarction (PROVE IT-TIMI 22) trial. Am Heart J 2008; 155:49-55.

30 Burkhardt K, Schwarz S, Pan C, Stelter F, Kotliar K, Von Eynatten M, Sollinger D, Lanzl I, Heemann U, Baumann M: Myeloidrelated protein 8/14 complex describes microcirculatory alterations in patients with type 2 diabetes and nephropathy. Cardiovasc Diabetol 2009;8:10

- 31 Ionita MG, Catanzariti LM, Bots ML, de Vries JP, Moll FL, Kwan Sze S, Pasterkamp G, de Kleijn DP: High myeloid-related protein: 8/14 levels are related to an increased risk of cardiovascular events after carotid endarterectomy. Stroke 2010;41:2010-2015.

32 Chobanian AV, Bakris GL, Black HR, et al: Seventh report of the Joint National Committee on Prevention, Detection, Evaluation, and Treatment of High Blood Pressure. Hypertension 2003;42:1206-1252. 
-33 CANADA-USA (CANUSA) peritoneal dialysis study group. Adequacy of dialysis and nutrition in continuous peritoneal dialysis: association with clinical outcomes. J Am Soc Nephrol 1996;7:198-207.

-34 Chan TM, Yung S: Studying the effects of new peritoneal dialysis solutions on the peritoneum. Perit Dial Int 2007;27(suppl 2):S87S93.

-35 Schilte MN, Celie JW, Wee PM, Beelen RH, van den Born J: Factors contributing to peritoneal tissue remodeling in peritoneal dialysis. Perit Dial Int 2009;29:605-617.
36 Szeto CC, Kwan BC, Chow KM, Lai KB, Chung KY, Leung CB, Li PK: Endotoxemia is related to systemic inflammation and atherosclerosis in peritoneal dialysis patients. Clin J Am Soc Nephrol 2008;3:431-436.

37 Szeto CC, Kwan BC, Chow KM, Lai KB, Pang WF, Chung KY, Leung CB, Li PK: Endotoxemia is associated with better clinical outcome in incident Chinese peritoneal dialysis patients: a prospective cohort study. Perit Dial Int 2010;30:178-186.

38 Suryono, Kido J, Hayashi N, Kataoka M, Nagata T: Effect of Porphyromonas gingivalis lipopolysaccharide, tumor necrosis factor-alpha, and interleukin-1beta on calprotectin release in human monocytes. J Periodontol 2003;74:1719-1724.
39 Kido J, Hayashi N, Kataoka M, Nagata T: Calprotectin expression in human monocytes: induction by porphyromonas gingivalis lipopolysaccharide, tumor necrosis factor-alpha, and interleukin-1beta. J Periodontol 2005; 76:437-442.

40 Ikemoto M, Tanaka T, Takai Y, Murayama H, Tanaka K, Fujita M: New ELISA system for myeloid-related protein complex (MRP8/14) and its clinical significance as a sensitive marker for inflammatory responses associated with transplant rejection. Clin Chem 2003;49:594-600. 